\title{
Use of Patient Preference Form to Evaluate Patients Satisfaction of OBGYN Outpatient Service in Dr. Wahidin Sudirohusodo Hospital Makassar - Indonesia
}

\author{
Eddy Hartono, Shandy Suwanto Putra, Elizabeth Catrina Jusuf, Umar Malinta
}

Department of Obstetrics and Gynecology, Faculty of Medicine, Universitas Hasanuddin, Makassar, Indonesia

Email address:

eddyhartono_spog@yahoo.com (E. Hartono)

To cite this article:

Eddy Hartono, Shandy Suwanto Putra, Elizabeth Catrina Jusuf, Umar Malinta. Use of Patient Preference Form to Evaluate Patients Satisfaction of OBGYN Outpatient Service in Dr. Wahidin Sudirohusodo Hospital Makassar - Indonesia. American Journal of Clinical and Experimental Medicine. Vol. 5, No. 2, 2017, pp. 56-59. doi: 10.11648/j.ajcem.20170502.16

Received: February 17, 2017; Accepted: March 1, 2017; Published: March 20, 2017

\begin{abstract}
Patient satisfaction can be measured by five dimension: tangibles, realibility, responsiveness, assurance and emphaty. All of which shown from the satisfaction level of patient, especially from doctor-patient communication. Nowadays, doctor-patient communication has already shifted from paternalistic to patient centered communication, so it required efforts to improve effective communication. Patient preference form is a questionnaire which filled by the patient before meeting the doctor which contains the patient's anxiety level, the problem which is the main purpose of visitation, as well as the selection of the type of communication to be used by doctors. This study aims to know the use of patient preferences form to evaluate patient satisfaction of Obgyn outpatient service in Dr Wahidin Sudirohusodo hospital, Makassar. This was an descriptive observational study which was conducted in Obgyn outpatient service of Dr Wahidin Sudirohusodo Hospital, Makassar. The samples were 50 respondents using consecutive sampling method. The patient preference form was given to respondents before meeting doctor and given the questionnaire and interview afterward. This study revealed that $64.0 \%$ of respondents felt really anxious before the meeting, $92.0 \%$ chose friendly language than formal. $82.0 \%$ satisfied with the service and felt the anxiety degree were lowering after the meeting. $92.0 \%$ said the main purpose have been achieved but only $74.0 \%$ felt the doctor use the right language like they chose before. $90 \%$ respondents felt the patient preference form were useful. Patient preference form can be used to evaluate patient satisfaction of Obgyn outpatient service in BLU Dr Wahidin Sudirohusodo hospital, Makassar, especially improving effective doctor-patient communication. The threats and weeakness can be pressed by doctor communication training and also by adjusting patient preference form with Indonesia situation and Obgyn field.
\end{abstract}

Keywords: Patient Preference Form, Communication, Satisfaction, Outpatient

\section{Background}

Dr. Wahidin Sudirohusodo Hospital Makassar is a government hospital that was found in 1994 based on the decree of the Indonesian Health Minister no. 540/SK/VI/1994 as type A hospital and as a teaching hospital as well as the highest referral hospital in eastern Indonesia. Based on the Government Regulation No. 23. 2005, the Wahidin Sudirohusodo Hospital has become Public Service Agency (Badan Layanan Umum). [1, 2] As a service provider, the Wahidin Sudirohusodo Hospital should provide highest service qualities in accordance with the seven pillars of health care qualities (efficacy, effectiveness, efficiency, optimalities, acceptability, legitimacy, and equity). As a result, health care professionals should consider patient preferences and social preferences in assessing and ensuring the quality. [3]

Monitoring and measurement of customer satisfaction has become a fundamental requirement for all service providers. Various ways can be done to measure the level of patient satisfaction, one of which was the consumer satisfaction surveys. Through surveys, service providers will obtain responses and feedback directly from the consumers, as well as provide positive credibility that service providers pay attention to the consumers. Customer satisfaction survey methods that can be used is the measurements based on 
SERVQUAL (service quality). Measurement of this models based on the multi-scale items designed to measure customer expectations and perceptions as well as the gap between them in five dimensions of service quality; Tangible, Reliability, Responsiveness, Assurance, and Empathy, all of these can be seen in how the communication between the doctor and patient. [4]

Over the last 20 years, there has been a prominent shift in from paternalistic, where doctors make all the decisions to the patient-centered model. The "patient centered" model emphasizes the importance of understanding the patient's experience of their disease, as well as relevant social and psychological factors. This means that doctors using more active listening skills. In this era of "patient centered", effective communication is indispensable, thus the doctor can understand the patient as a whole person, exploring the illness and the pain experiences of patient. Finally, it is will increase the patient satisfaction, the use of cost effective of health resource and reduce the possibility of malpractice accusations. Moreover, most of dissatisfaction with physicians is related to communication problems instead of clinical competence. [5]

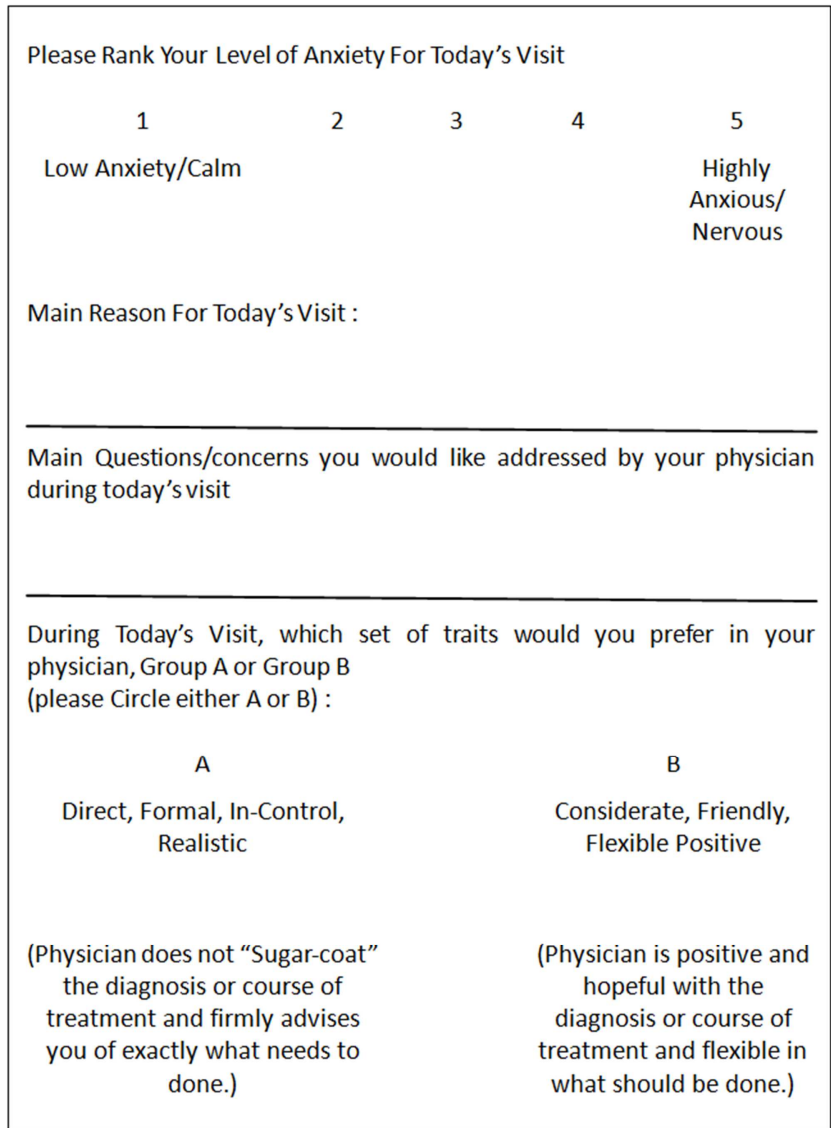

Figure 1. Patient Preferences Form (Adapted from Models From ClinicalMedicine Insights: Women Health, 2010). [6]

The existing barriers to communicate, especially patientdoctor communications may inhibit the searching of information and history, as well as the barrier in communication techniques will inhibit the providing of explanation and education to patient. These barriers can be reduced by increasing the sensitivity level of the doctor to the patient, because each patient is a unique individual. [6]

Patient Preferences Form (PPF) is a questionnaire paper distributed and filled by a patient before seeing the doctor. This paper is comprised of the patient's anxiety level during the visit, the main reason for his visit, the main question at the time of visit, the type of communication selected at the time seeing the doctor.

The patient's self-indicated level of anxiety may provide a sign as to the communication style the patient prefers and the precaution that should be taken by the physician during the medical interview to attempt to alleviate rather than heighten patient anxiety. Assessing the patient's main reason for their current visit as well as their main questions and concerns prior to the visit may ensure the patient's needs are fully met by the conclusion of the medical interview. Prior knowledge of the patient's needs may lead to a more satisfying and efficient medical interview for both the patient and the physician. [6]

The final portion of the questionnaire will address the patient's communication style preferences. Side A of the communication style chart represents traits of a biomedical physician, while side $B$ represents traits of a patient-centered physician. [6]

Based on those background above, the writer wanted to know the use of patient preferences form in evaluate patient satisfaction of outpatient obstetrics and gynecology services at Dr. Wahidin Sudirohusodo Hospital, Makassar.

\section{Materials and Methods}

This study was a descriptive observational study conducted in the Obstetrics and Gynecology outpatient clinic of Dr. Wahidin Sudirohusodo Hospital, Makassar. The samples in this study were conducted using consecutive sampling with total 50 respondents. Respondents were given PPF before meeting with the doctor, then PPF attached to medical records of the respondent. Before meeting with the patient, the doctor read the Patient Preference Form. After the visit, patients were assessed with questionnaires and indepth interview about the level of satisfaction, the level of anxiety and whether PPF was useful or not. Data is displayed in tabular form and in the narative ways.

\section{Results and Discussion}

After 50 respondents filled the questionnaire and in-depth interviews, we got characteristic of respondents as shown in Table 1.

Table 1. Respondents Characteristics.

\begin{tabular}{lll}
\hline Respondents Characteristics & Total & $\mathbf{\%}$ \\
\hline & $\mathbf{n = 5 0}$ & \\
\hline Age & & \\
$\leq 16$ years old & 4 & 8.0 \\
$16-35$ years old & 18 & 36.0 \\
$\geq 35$ years old & 28 & 56.0 \\
\hline
\end{tabular}




\begin{tabular}{lll}
\hline Respondents Characteristics & Total & \% \\
\hline & $\mathbf{n = 5 0}$ & \\
\hline Education Levels & 32 & 64.0 \\
Low (Junior High and below) & 38 & 36.0 \\
High (Senior High and above) & 18 & \\
Working Status & & 72.0 \\
No & 36 & 28.0 \\
Yes & 14 & \\
Billing Status & & 88.0 \\
BPJS (Insurance) & 44 & 12.0 \\
Doesn't have any Insurance & 6 & \\
Referal Status & & 86.0 \\
Yes & 43 & 14.0 \\
No & 7 & \\
Visit & & 70.0 \\
First time & 35 & 30.0 \\
Second time or more & 15 & \\
Cases & & 48.0 \\
Obstetric & 24 & 52.0 \\
Gynecologic & 26 & \\
\hline
\end{tabular}

The assessment criteria of the Patient Preference Form (before and after the visit) shown in Tables 2 and 3. In this study showed that most of respondents came with high levels of anxiety. This can be explain that almost all respondents who came to the clinic were referral patients that their problems could not be resolved at lower level of health facilities. It was as stated by the majority of respondents who were the referral one. After the visit, $92.0 \%$ of those felt the main purpose of the visit were reached, but only $84.0 \%$ of the respondents felt reduce in levels of fear and satisfied with the services provided. One of the respondents said that in fact the doctor had known what the main problems that she worried, but when giving an explanation, the doctor had not yet reassuring the respondent, and patient still felt anxious with the condition she suffered. This is consistent with previously studies that the age, education level, working status may affect the level of anxiety of obstetric patients. High-risk pregnancy age, low education level and no work have higher levels of anxiety. The first visit or meet with new medical personel may also affect the level of service and anxiety in patient. [7] In medical communication, patient often having anxiety when visiting the doctor, and then influencing the interaction between them. [5] A good communication can be therapeutic to reduce anxiety. Decreased anxiety of patients will also reduce the level of use of other supporting tools, repeated visits and the level of referrals to more high health facilities. [7, 8]

Table 2. Patient Preference Form Points Before The Meeting.

\begin{tabular}{lll}
\hline Point & Total & $\mathbf{\%}$ \\
\hline & $\mathbf{n = 5 0}$ & \\
\hline Anxiety Levels of patient Before Meeting & & \\
No anxiety & 0 & 0 \\
Low Anxiety & 18 & 36.0 \\
High Anxiety & 32 & 64.0 \\
Language Type that Patient Chose & & \\
Formal Language & 4 & 8.0 \\
Friendly/ Informal & 46 & 92.0 \\
\hline
\end{tabular}

The language chosen by the majority of respondents are friendly languages $(92.0 \%)$ than formal language $(8.0 \%)$.
After the visit, only $74.0 \%$ of respondents felt their doctor use the language preferred by the patient. One of the respondents said that she chose friendly language because easier to understand what the doctor said. One of the respondents also said that the doctor was not consistent in using the types of languages when explain the disease and planning treatment, sometimes understandable, sometimes not. This is consistent with other study showed that the selection of patient-based communication is preferred by most patients (67-74\%). Age, education and work are also factors that may influence the choice of the language where the age above 60 yeras old, and low education prefer the use of formal and direct language. It is not seen in this study due to the small number of respondents and many other factors influencing. [9]

Table 3. Patient Preference Form Point After The Meeting.

\begin{tabular}{lll}
\hline Point & Total & \% \\
\hline \multicolumn{1}{l}{$\mathbf{n = 5 0}$} & \\
\hline Patient Satisfaction to the Service & 41 & 82.0 \\
Satisfy & 9 & 18.0 \\
No & & \\
Anxiety Level of Patient After Meeting & 42 & 84.0 \\
Reducing & 8 & 16.0 \\
Not reducing (still the same level) & & \\
Main Purpose of The Visit Achieved & 46 & 92.0 \\
Yes & 4 & 8.0 \\
No & & \\
Doctor use Language as Chosen by Patient & 37 & 74.0 \\
Yes & 13 & 26.0 \\
No & & \\
Usefullnes Of PPF & 45 & 90.0 \\
Useful & 5 & 10.0 \\
No & & \\
\hline
\end{tabular}

Patient Preference Form were said to be useful by the majority of respondents $(90 \%)$. The reasons given include assisting patients in addressing the unexpressed problems when meeting with doctors who were strangers for them. Feeling shy, fearful and anxious prevent them to start talking, and the use of language in communicating that easier to be understood by the patient. The obstacle perceived by the respondents were the difficulty of reading and writing due to older age and no education, the use of language in patient preference form that is still difficult to understand by respondents, and feelings anxiety and fear that preventing them in writing what the main problem of their visit. This is consistent with other study showed that problems in Southeast Asia peoples, to perform the effective doctorpatient communication include less time for each patient, the gap of the education levels between of doctor and patients and unpreparedness of doctor adapting to the desired language of patients. [10]

\section{Conclusions and Recommendations}

Based on the results and the discussion above, it can be concluded that people who visited to the Obstetrics and Gynecology Outpatient clinic of Dr. Wahidin Sudirohusodo Hospital are patients with high levels of anxiety, and patients 
prefer to use informal language. Most patients were satisfied with the services provided. The use of the Patient Preference Form can be one way to assess patient satisfaction in Obstetrics and Gynecology Outpatient Services at Dr Wahidin Sudirohusodo Hospital, Makassar. The Patient Preference Form could be a tool to build effective doctorpatient communication, and as a medium in anticipating the barriers to create the effective communication. The author also suggested further study with larger samples to increase the use of the Patient Preference Form in Obstetrics and Gynecology. In addition, Patient Preference Form should be supported by increaseing communication training of service providers in this case are the doctors in order to adapt to many types of communication.

\section{References}

[1] Anonim. (2015). Sejarah RS Dr. Wahidin Sudirohusodo Makassar. Diakses 27 Februari 2016. Available from: http://www.rsupwahidin.com/homepage/?page= sejarah

[2] Peraturan Pemerintah No 23 tahun 2005 tentang Pengelolaan Keuangan Badan Layanan Umum, Jakarta.

[3] Donabedian A. (1990). The Seven Pillars of Quality. Arch. Pathol. Lab. Med, 114 (11): 1115-1118.
[4] Tjiptono F. (2000). Perspektif Manajemen dan Pemasaran Kontemporer. Yogyakarta: Penerbit Andi.

[5] Levinson W, Lesser C S, Epstein R M. (2010). Developing Physician Communication Skills For Patient Centered Care. Health Affairs, 29 (7): 1310 - 1318.

[6] Yeh J \& Nagel E E. (2010). Patient Satisfaction in Obstetric and Gynecology: Individualized Patient-centered Communication. Clinical Medicine Insights: Women Health, 3: 23-32.

[7] Kasana N. (2014). Hubungan antara komunikasi terapeutik dengan tingkat kecemasan pada pasien pre operasi Sectio Caesarea di ruang PONEK RSUD Karanganyar (Skripsi). Surakarta.

[8] Bertakis K. D \& Azari R. (2011). Patient-Centered Care is Associated with Decreased Health Care Utilization. The Journal of the American Board of Family Medicine, 24 (3): 229-239.

[9] Swenson S. L. et al. (2004). Patient- centered Communication: Do Patients Really Prefer It?. Journal of General Internal Medicine, 19: 1069-1079.

[10] Claramita M, Utarini A, Soebono H, Van D J, Vleuten V D. (2011). Doctor Patient Communication in A Southeast Asian Setting: The Conflict Between Ideal and Reality. $A d v$ in Health Sci Educ, 16: 69 - 80. 